\title{
Prehistoric Ceramics from the Browning Site (41SM195A)
}

\section{Mark Walters}

Heritage Research Center, Stephen F. Austin State University

Follow this and additional works at: https://scholarworks.sfasu.edu/ita

Part of the American Material Culture Commons, Archaeological Anthropology Commons, Environmental Studies Commons, Other American Studies Commons, Other Arts and Humanities Commons, Other History of Art, Architecture, and Archaeology Commons, and the United States History Commons

Tell us how this article helped you.

This Article is brought to you for free and open access by the Center for Regional Heritage Research at SFA ScholarWorks. It has been accepted for inclusion in Index of Texas Archaeology: Open Access Gray Literature from the Lone Star State by an authorized editor of SFA ScholarWorks. For more information, please contact cdsscholarworks@sfasu.edu. 


\section{Prehistoric Ceramics from the Browning Site (41SM195A)}

Creative Commons License

(c) (i) (8)

This work is licensed under a Creative Commons Attribution-NonCommercial 4.0 International License 


\title{
Prehistoric Ceramics from the Browning Site (41SM195A)
}

\author{
Mark Walters
}

Archaeological work at the Browning site (41SM195A) in eastern Smith County, Texas, has shown that it is a stratified site with two very distinct occupations: an early nineteenth century assemblage of artifacts in the upper zone overlying a buried prehistoric occupation (Walters 2004a, 2004b). This occupation appears to be confined to the Woodland time period (ca. 500 B.C. to A.D. 800) with little evidence of any earlier or later prehistoric activity. The Woodland period in East Texas is a time of important cultural changes, "the most obvious (and most important?) of which is pottery-making and the bow and arrow" (Story 1990:243-249).

The main focus of the prehistoric occupation at the Browning site occurs in an organically enriched darker soil zone that is the result of either a continuous human occupation or frequent revisiting of this location, what Waters (1996) has described as archaeo-sediments resulting from human activity. This darker soil occupies the center of the landform and covers approximately $500 \mathrm{~m}^{2}$. It contains charred wood, charred nut shell, lithic debris from stone tool manufacture/maintenance, and small amounts of burned and unburned animal bone. Other artifacts in this distinct soil zone include small dart points, mostly varieties of Gary; arrow points, mostly of the Friley and Steiner types; ground stone tools; and ceramics, primarily plain grog-tempered wares.

Early work at the site included the excavation of $6.546 \mathrm{~m}^{3}$ of archaeological deposits from 101 $\mathrm{x} 1 \mathrm{~m}$ test units plus 22 shovel tests, resulting in the recovery of numerous historic and prehistoric artifacts, including eight Woodland period sherds (Walters 2004a, 2004b). To date, excavations at the Browning site have totaled $20.4 \mathrm{~m}^{3}$ of archaeological deposits from $411 \times 1 \mathrm{~m}$ test units. The total amount of sherds associated with the Woodland occupation now totals 40 pieces. Those sherds, which are described in some detail and compared with other known sites, are the focus of this article. These sherds are scattered evenly across the occupation area in low densities.

\section{STRATIGRAPHY}

To shed some light on the sequence of events at the Browning site, specifically the introduction of new technology - such as the advent of the bow and arrow or the introduction of pottery-I compare the relative depth of pottery sherds, arrow points, and dart points in the archaeological deposits. To do this, I am assuming that the archaeological deposits on the landform are uniform in depth across the site, which they are not, resulting in some compression of the archaeological deposits in certain areas where the soils are thinner. However, $65 \%$ of the sherds are found from $20-40 \mathrm{~cm}$ bs, whereas $58 \%$ of the dart points are found at the same depths. By comparison, $57 \%$ of the arrow points also are found from $20-40$ $\mathrm{cm}$ bs, with an additional $26 \%$ found from $40-50 \mathrm{~cm}$ bs. Thus, vertical stratification in the Browning site archaeological deposits indicates no significant differences in the depth of the dart points, arrow points, and ceramics, suggesting that these material remains are of the approximate same age in the Woodland period component; the number of arrow points found below $40 \mathrm{~cm}$ bs also suggests that at the time of the initial occupation of the site, the Woodland period group had already adopted arrow points.

\section{ASSOCIATED STONE TOOLS}

Friley and Steiner are the most commonly recognized types of arrow points of the 35 arrow points that have been collected at the Browning site to date. Other stone tools include flake tools, seven ferruginous sandstone ground stone tools, and 12 dart points, with small Gary points the most common type (Webb et al. 1969). Dr. Harry Shafer is 
conducting a detailed analysis of the lithic artifacts from the site.

The 47 arrow and dart points occur at a density of 2.3 per $\mathrm{m}^{3}$. Recent excavations $\left(11.35 \mathrm{~m}^{3}\right)$ at Leaning Rock (4ISM325), a nearby Caddo site that dates to the mid $14^{\text {th }}$ century, yielded a total of 12 arrow and dart points or only 1.06 points per $\mathrm{m}^{3}$ of archaeological deposits (Shafer 2007). This difference suggests that through time in this part of East Texas, from the Woodland period through the Middle Caddo period, stone artifacts decrease as a percentage of the total artifacts in archaeological assemblages, probably because of an increased reliance by local populations on plant foods (especially maize) through time.

\section{DATING OF THE BROWNING SITE}

A sample of charred nutshell $(\mathrm{Cl} 3 / \mathrm{C} 12=-25.3)$ (6.9 grams) collected from near the bottom of the archeologicul deposits in Unit I $(40-50 \mathrm{~cm}$ bs) was submitted for radiocarbon dating by Bcta Analytic. Inc. The conventional age of the sample (Beta170727 ) is $1.310 \pm 70$ B.P. The calibrated intercept is AD 685 , and at two sigma, there is a $95 \%$ probability that the calibrated age of the charred nutshell falls between AD 625 to 880 .

Oxidizable Carbon Ratio (OCR) samples were also collected from Unit 1 . The OCR samples were collected in a column starting at $11 \mathrm{~cm}$ bs and continuing at $10-15 \mathrm{~cm}$ intervals levels to $56 \mathrm{~cm}$ bs. The OCR dates from the midden zone (26-46 $\mathrm{cm}$ bs) indicatc that the sediments comprising the midden began to form after about A.D. 145, with the dates of ca. A.D. 357-815 indicating when the Browning site was most intensively occupied in prehistoric times.

A second radiocarbon sample (a charred nutshell, $13 \mathrm{C} / 12 \mathrm{C}=-24.0$ ) was submitted in 2008 to Beta Analytic (Beta-244134) for AMS dating from Unit $33,39 \mathrm{~cm}$ bs. The conventional age is 830 \pm 40 B.P. The calibrated intercept is AD 1220. At two sigma, therc is a $95 \%$ chance that the age falls between AD I160 to 1270. Based on the artifacts collected from the Browning site and the other supporting radiocarbon and OCR dates, this date appears to be scveral hundred years too young. Experience has shown that multiple dates (ca. 10 or more) are needed to accurately date prehistoric occupations. Hopefully, more dates can be obtained down the road that will form a better picture of the agc span when the Browning site was occupied by prehistoric peoples. Toward that effort a plain rim sherd from Unit $38,28 \mathrm{~cm}$ bs, has been submitted in Octuber 2008 to the University of Washington for thermoluminescence (TL) dating.

\section{PREHISTORIC CERAMICS F RONI THE BROW VING SITE}

From excavations to date. a total of 40 prehistoric sherds have been collected from the Browning site. This is a density of 0.98 sherds per $\mathrm{m}^{2}$ and 1.96 sherds per $\mathrm{m}^{3}$. The 40 sherds, including two rims, have an average thickness of $6.5 \mathrm{~mm}$, with a range from 4.2 $\mathrm{mm}$ to $11.3 \mathrm{~mm}$ : 11 sherds are less than $5 \mathrm{~mm}$ thick. No recognizable bases have been collected.

\section{Surface Ireatment}

The sherds are well-made and $85 \%$ have exterior/interior smoothed surfaces. Threc $(7.5 \%)$ of the sherds are smoothed only on the exterior surface. and one $(2.5 \%)$ sherd is burnished on the exterior surface. Two $(5 \%)$ sherds are eroded, prohibiting any positive identification regarding surfacc treatment.

\section{Temper}

Twenty-cight $(70 \%)$ of the sherds are grogtempered. Another $15 \%$ have grog/hematite temper. Four $(10 \%)$ have a combination of grog and bone as tempering agents; none of these sherds have an abundance of bone. Two (5\%) sherds have no discernible temper.

Sixteen $(40 \%)$ of the sherds have a sandy paste evidenced by the visual appearance of varying amounts of quart7 grains in the clay matrix. ut though there is nol enough sand present to make the sherds feel "gritty." Some amounts of sand are to be expected in the clay paste of local ceramics, as most clay sources in the areat are primary clays derived from the sandstone parent malerial underlying this portion of East Texas.

\section{Firing}

Twenty-six $(65 \%)$ of the sherds have been fired and cooled in a reduced oxygen atmosphere. Thirteen $(32.5 \%)$ were fircd in a reducing atmosphere, and then allowed to cool in the open air. One sherd $(2.5 \%)$ was completely oxidized during firing. 


\section{Hardness}

Ten sherds collected at random from the Browning site collection have hardness values that range from 2.5 to just over 4.0 on the Moh scale, with a mode of 3.2. This compares to Williams Plain sherds, which tend to be solt and chalky, with a mode of 2.5 . (Schambach 1998:24). Sherds from local Caddo sites average 3.3 in hardness (Walters 2008:46-48).

\section{Decoration}

With a plain to decorated sherd ratio of 5.67 , six $(15 \%)$ of the sherds at the Browning site are decorated. Three body sherds have single straight incised lines, while two sherds had two parallel straight incised lines; the distance between the incised lines ranges from $12.2-13.0 \mathrm{~mm}$. The decoratcd rim, from Unit $37,10-20 \mathrm{~cm}$ bs, has a single straight horizontal incised line on it that is $8.0 \mathrm{~mm}$ below the lip, 1.5 $\mathrm{mm}$ wide, but does not overhang.

\section{Vessel Form}

Unfortunately, the small number and size of the 40 sherds contribute little information on the types of vessels made and used at the Browning site. Nevcrtheless, all of the sherds indicate that the vessels were made using coil construction, and all but two sherds have evidence of smoothing on the exterior and/or interior surfaces, indicating that the sherds are from vessels that are open containers, namely jars and howls, as opposed to hottle forms, whose walls could be readily smoothed.

No identifiable bases were recovered so it could not be determined if the vessel bases were flat or rounded. One sherd from Unit $27(30-40 \mathrm{~cm}$ bs) may be a portion of a base as part of the sherd has a slight curve and thickened from $7.0 \mathrm{~mm}$ to $8.61 \mathrm{~mm}$.

One small rim (Unit 37, 10-20 cm bs) has a direct or vertical profile with a rounded but slightly exterior folded lip. No estimate of orifice diameter was possible. although the smoothing of both interior and exterior surfaces indicate it is from an open container. Sherd thickness tapered from $3.9 \mathrm{~mm}$ at the lip to $4.9 \mathrm{~mm}$ on the vessel body wall where the break occurred. This is typical of coil construction where the vessel is built from the bottom up, resulting in vessel walls that become thinner with height.

The sccond rim (Unit $38.28 \mathrm{~cm} \mathrm{bs)} \mathrm{is} \mathrm{from} \mathrm{what}$ appears to be a plain carinated bowl. The break occurs just below the carination point but enough remains of the rim to indicate a sharp $30-40^{\circ}$ angle from the rim and the remainder of the body of the vessel. The rim is direct and tapers from $3.9 \mathrm{~mm}$ thick at the lip to $6.0 \mathrm{~mm}$ at the carination point on the vessel wall. The orifice diameter of the carinated bowl is $18.0 \mathrm{~cm}$. This sherd has been submitted for TL dating.

\section{Instrumental Neutron Activation Analysis (INAA)}

Two sherds from the Browning site were submitted for INAA (Walters 2004a, 2004b) Both sherds were assigned at the time to the Titus chemical group (Descantes et al. 2003:Table 5; Perttula 2002:92-94), suggesting that the sherds were from vessels made from local clays.

\section{COMPARISON WITH OTHER WOODLAND SITES}

The Broadway site (41SM273) is located in central Smith County, Texas, some 10 miles west of the Browning site. A late Woodland period occupation (dating after ca. A.D. 500/600) was identified from the work there (Perttula and Nelson 2004:155-161), as were later Caddo components. In this report, Pcrttula defines a Mill Creek Culture, in the Sabine River basin of East Texas, that is contemporaneous with the Fourche Maline and Mossy Grove cultures to the south and north (Figure 1). At the Broadway site, the few ceramies associated with the Woodland occupation werc primarily grog-tempered, but with significant amounts of bone and hematite. The sherds at Broadway averaged about $7 \mathrm{~mm}$ in thickness, not much different from the average thickness of $6.5 \mathrm{~mm}$ from the Browning site. Approximately $13 \%$ of the sherds were decorated with simple incised elements and tool and fingernail punctations compared to $15 \%$ of the sherds at the Browning site that have incised decorations. Stone tools associated with the Woodland occupation at Broadway include small dart points, mostly of the Gary type. and Steiner/Friley arrow points.

The Herman Bellew site (4IRK222) is located some 20 miles southeast of the Browning site. Extensive excavations there defined a Woodland occupation that dated between 200 B.C. and A.D. 800. Ceramics at the Herman Bellew site were sparse, averaging 1.3 sherds per $\mathrm{m}^{2}$ compared to 0.98 sherds per $\mathrm{m}^{2}$ at the Browning sitc. Most of 


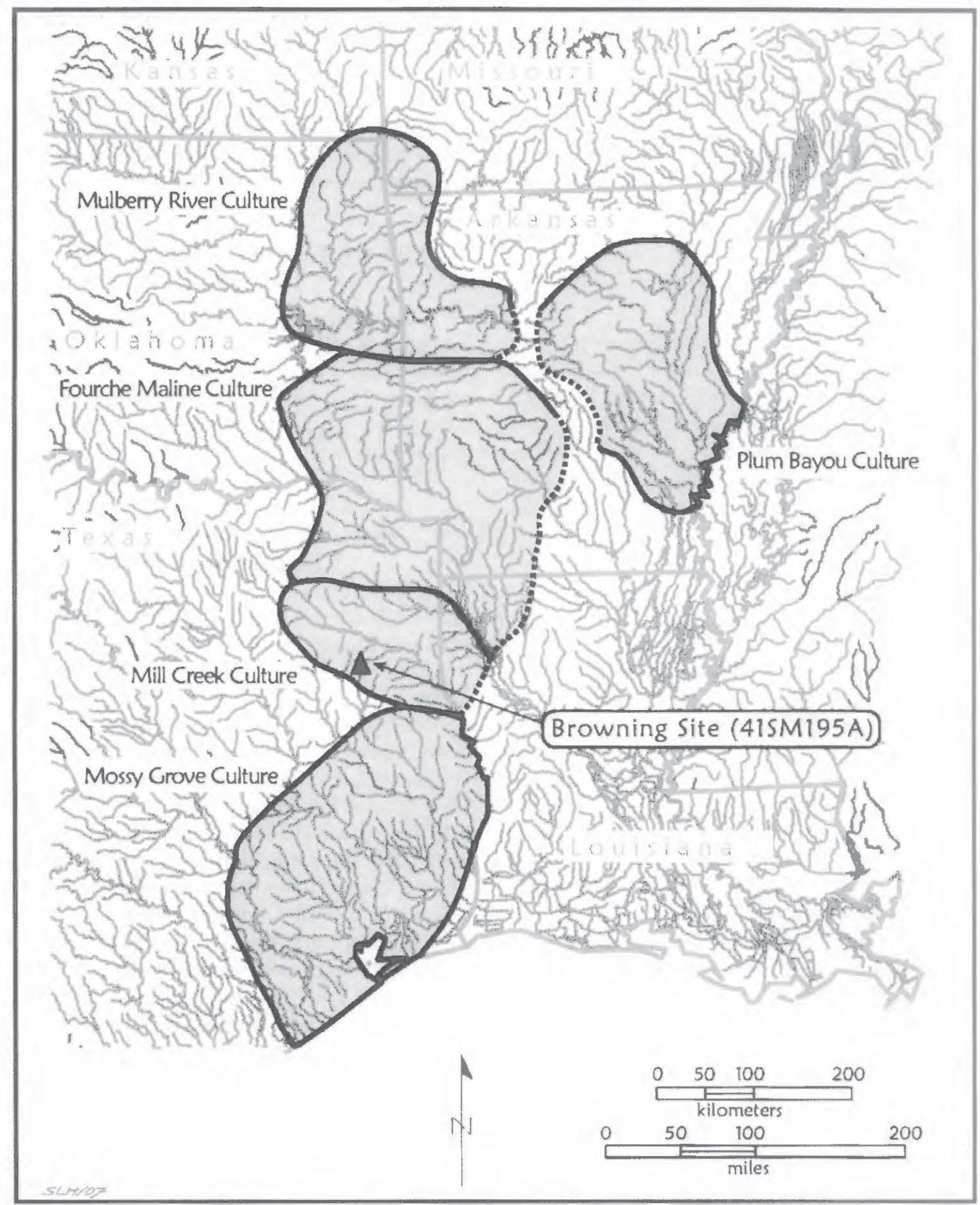

Figure 1. Map of Woodland cultures in the Caddo area, including the Mill Creek Culture, and the location of the Browning site in East Texas. 
the sherds at the Herman Bellew site were plain, and with a mix of sandy paste wares, bone-tempered wares, and thinner grog-tempered wares, thosc being identified with the post-A.D. 400 occupation (Rogers et al. 2001). Decorations on the sherds were primarily simple punctated and incised elements. Associated stone tools included several varieties of Gary points with a few Kent and Ellis dart points. and after A.D. $600 / 700$ there were Friley arrow points.

The Dogwood Trail No. 1 site (16BO574), some 75 miles east of the Browning site, is situated near the edge of the floodplain of a small, unnamed tributary of the Red River in northern Bossier Parish, Louisiana (Girard 2005). The site consists of a scatter of prehistoric pottery and stone artifacts from a single prehistoric component. One radiocarbon date yielded an age of $1484 \pm 41$ B.P. (UGA00880, wood charcoal, $\delta=-24.8$ ), with a calibrated age at two sigma of AD 531 to 650 , indicating occupation early in the Late Woodland period.

Of the 1205 recovered sherds, only seven $(0.6 \%)$, were decorated. The rarity of decorations on the pottery distinguishes the collection from later Caddo occupations in Northwest Louisiana and East Texas.

Five of the decorated sherds are body sherds with incised lines that most likely are horizontal. One specimen appears to have either linear punctations beneath a horizontal line or incised lines in two directions. Another specimen has at least one horizontal incised line $7.5 \mathrm{~mm}$ below the lip. The sherd appears to be from a bowl and there are two lip lines on the flat vessel lip. Although the surfaces are not polished and the lines do not overhang, the sherd resembles either the Campbellsville or Macedonia varieties of the type Coles Creek Incised (Phillips 1970:71,75; Girard 2005). Two parallel curvilinear incised lines are present on one small sherd, and the decorative element cannot be ascertained. The final decorated specimen has a series of short curved incised lines or punctations just below the lip.

The mean thickness of the sherds from the Dogwood Trail No. 1 site is high $(7.593 \mathrm{~mm})$ relative to most later Caddo sites in the area, but within the lower range reported for the type Williams Plain (cf. Schambach 1998:Tables 4 and 10). Most of the sherds are betweer 6 and $9 \mathrm{~mm}$ thick, with a mode of $7 \mathrm{~mm}$. Sherd thickness is comparable to that from the early occupation at the Festervan site (16BO327) in the Red River floodplain where a mean sherd thickness of $7.32 \mathrm{~mm}$ was measured on a collection of 632 sherds. A radiocarbon date from this context calibrates at 2 sigma to the AD 657-894 interval (Girard 1994). In contrast, Early to Middle Caddo period sites generally have collections with mean sherd thickness less than $7 \mathrm{~mm}$.

The sherds have grog and sand inclusions and $51(4.2 \%)$ also have crushed bone. Three small sherds may be from vessels with relatively sharpangled shoulders.

All of the six arrow points recovered from the Dogwood Trail No. 1 site are broken or crudely chipped. One probable Catahoula point (Webb 2000:15) has deep corner notches, barbed shoulders, and an expanding stem. Similar arrow point forms have been found in other Late Woodland period contexts at the Fredericks and Onion Island sites (Girard 1994, 2000).

\section{DISCUSSION}

The material culture from the Woodland period component at the Browning site is characterized by a large number of stone tools, mostly small Gary dart points and numerous well-made Friley and Steiner arrow points, and only a small amount of mostly plain grog-tempered sherds. Based on only a few absolute dates, the presence of arrow points in apparent association with contracting dart points, and a limited amount of ceramics, it is difficult to accurately understand the place of the Browning site in a Woodland period culture or to determine when or how long it was occupied.

The Browning site falls within the geographic area of the Mill Creek Culture (Perttula and Nelson 2004). With the small number of sherds, and their general character, the sherds from the Browning site also has cultural traits that have been identified on other Mill Creek Culture components in East Texas. What is very evident is the meager amount of ceramics at the Browning site when compared to later Caddo sites in the area that are distinguished by their sheer volume of sherds. At the Browning site, the sherd density is only 1.96 sherds per $\mathrm{m}^{3}$. By comparison, in excavations at the Leaning Rock (41SM325) Caddo site, the sherd density is 280.4 sherds per $\mathrm{m}^{3}$ (Walters 2008). It is uncertain why there are so few sherds represented at Mill Creek Culture sites compared to that seen on Fourche Maline (Schambach 1998) or Mossy Grove sites (Story 1990), but evidently ceramics played a minor role in the lives of the people that lived at the Browning and other Mill Creek sites. 
It is noteworthy that the ceramics at the Browning site closely resemble later Caddo ceramics in thickness, surface treatmont, firing, and hardness, and to some extent with respect to vessel decoration, and they would be very hard to separate from the ceramic sherds on any nearby Caddo assemblage. However, with a small amount of sherds, it might be difficult to also distinguish between the Browning site grog-tempered ware and Williams Plain, the prineipal pottery type in Fourche Maline culture sites, although Williams Plain is defined as having a coarse texture, a relatively soft paste, and are generally thicker (average hody sherd thickness $=8.0 \mathrm{~mm}$ ), with heavy disk-shaped or square bases (Schambach 1998:24-26).

Evidence from the Browning site and the Dogwood Trail No. I site suggests that the carinated bowl form, usually defined as a Caddo ceramic trait, may have an earlier history than previously thought since possible carinated bowl sherds are present at both these Woodland period components. Carinated howl sherds have also been identified in a Mossy Grove Culture component in Nacogdoches County in East Texas (Timothy K. Perttula, October 2008 personal communication).

It will be interesting to follow future work at East Texas Woodland sites and see if and/or how the diverse Woodland cultures that have been defined in the area-Fourche Maline, Mossy Grove, and Mill Creek - evolved into what we have defined archaeologically as Caddo culture.

\section{REFERENCES CITED}

Descantes, Christophe, Robert J. Speakman, and Michael D. Glascock

2003 Letter Report to Timothy K. Perttula with enclosed figures and tables, September 3, 2003. University of Missouri Research Reactor, Columbia.

Girard. J. S

1994 Regional Archaeology Program, Management Unit 1. Fifth Annuul Report. Report on file at the Louisiana Division of Archaeology, Department of Culture. Recreation, and Tourism. Baton Rouge.

2000 Excavations at the Fredericks Site. Natchitoches Parish, Louisiana. Louisiana Archueology 24:1-106.

2005 The Dugwood Trail No. 1 Site (16BO574), Bossier Parish. In Regional Archaeology Program. Management Unit 1, Sixteenth Annual Report. Report on file at the I ouisiana Division of Archacology. Department of Culture, Recreation, and Tourism, Raton Rouge.
Perttula. T. K.

2002 Archaeological Evidence for the Long-Distance Exchange of Caddo Indian Ceramics in the Southern Plains, Midwest, and Southeastern Lnited States, In Geochemical Evidence for Long-Distance Exchange. edited by M. D. Glascock, pp. 89-107. Bergin and Garvey. Westport. Connecticut.

Perttula, T. K. and B. Nelson

2004 Woodland and Caddo Archeology at the Broudwan or Kanduts'ah Kuhnihdahahdisa' Site (4ISM273) on the Ciry of Tyler-Lake Palestine WTP Project. Smith County, Texas. Report of Investigations No. 50. Archeological and Environmental Consultants. LLC, Austin.

Phillips. P.

1970 Archaeological Survey in the Lower Yazoo Bas'" Mississippi, 1949-1955. Paper of the Peabody Museum of Archaeology and Ethnology, Vol. 60. Harvard University, Cambridge, Massachusetts.

Rogers, K.. M. Nash, and T. K. Perttula

2001 Excavations at the Herman Bellew Site (41RK222), Rusk Count, Jexas. Document No. 000021 . PBS\&J. Austin.

Schambach. F. F.

1998 Pre-Caddoan Cultures in the Trans-Mississippi South: A Beginning Sequence. Research Series No. 53. Arkansas Archeological Survey, Fayetteville.

Shafer, H. J.

2007 Leaning Rock Site (41SM325) Lithics. Caddo Archeological Journal i 6:57-70.

Story, D. A.

1990 Cultural History of the Native Americans. In The Archenlogy and Bioarcheolog! of the Gulf ( astal Plain, by D. A. Story, J. A. Guy, B. A. Burnett. M. D. Irreeman. J. C. Rose, I). G. Steele. B. W. Olive, and K. J. Reinhard, pp. 163-366. 2 Vols. Research Series No. 38. Arkansas Archeological Survey, Fayettevillc

Walters, Mark

2004a 41SM195A. The Browning Site. Fournal of Northeast Texas Archaeology 20:1-42.

2004b 4ISM195A. The Browning Site. Caddoan Archeology. Journal $13(3 / 4): 19-20$.

2008 Life on Jackson Creek, Smith County, Texas: Ar cheological Investigations of a $14^{\text {th }}$ Century Caddo Domicile at the Leaning Rock Site (41SM325). Caddo Archeology Journal 17:1 114.

Waters, M. R.

1996 Principles of Geoarchaenlog!. The University of Arizona Press. Tucson. 
Webb, C. H.

2(1)(0) Stone Points and Tools of Northwestern Louisianu. Special Publication No. 1. Louisiana Archaeological Society, Baton Rouge.
Webb, C. H., F. E. Murphey. W. G. Ellis, and H. R. Green

1969 The Resch Site, 41HS16, Harrison County, Texas. Bulletin of the Texas Archeological Society 40:3106. 